\title{
The General Ban on Aerial Spraying of Pesticides of the European Union: The Policy-Making Process Between 1993-2009
}

Hannah M. Zwetsloot, Lisette Nikol, and Kees Jansen 
Zwetsloot, Hannah M., Nikol, Lisette, and Jansen, Kees, 2018. The General Ban on Aerial Spraying of Pesticides of the European Union: The Policy-Making Process between 1993-2009. Wageningen, Rural Sociology. 34 pp.; 1 tab.; 62 ref.; DOI: https://doi.org/10.18174/442443

A pdf version of this work will be made available as Open Access via http://edepot.wur.nl This report can also be downloaded for free at https://doi.org/10.18174/442443

This work is licensed under the Creative Commons Attribution-Non Commercial 4.0 International License, http://creativecommons.org/licenses/by-nc/4.o/

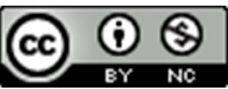

(C) 2018, Hannah M. Zwetsloot, Lisette Nikol, and Kees Jansen

\section{Rural Sociology Group}

Wageningen University

Hollandseweg 1

$6706 \mathrm{KN}$ Wageningen

The Netherlands

www.wur.nl/rso

Although all care is taken to ensure integrity and the quality of this publication and the information herein, no responsibility is assumed by the publishers, the author nor Wageningen University for any damage to the property or persons as a result of operation or use of this publication and/or the information contained herein.

This is a non-peer reviewed report. Data collection and document analysis were carried out by Hannah Zwetsloot. 


\section{Contents}

Prologue 1

Introduction $\quad 3$

Environment Action Programmes 3

Fifth Environment Action Programme, 1993-2000 4

Sixth Environment Action Programme, 2002-2010 5

First Proposal for a Thematic Strategy on the Sustainable Use of Pesticides, $2002 \quad 6$

Consultations following Commission's First Proposal, 2002-2005 7

Consultations regarding Commission's First Proposal, 2002-2003

Expert Meetings, 2003-2004 10

External Consultancy, 2004-2005 11

Interactive Policy Making Consultation, March-May $2005 \quad 14$

Final Remarks

Second Proposal for a Thematic Strategy on the Sustainable Use of Pesticides, $2006 \quad 15$

Commission's Extended Impact Assessment, 12/7/2006 15

Commission's Draft Directive, 12/7/2006 16

Final Remarks $\quad 16$

EU Co-Decision Procedure, 2006-2009 17

European Economic and Social Committee, 14/3/ $2007 \quad 17$

European Parliament: First Reading, 23/10/2007 17

Commission: Opinion on European Parliament's First Reading, 23/10/2007 18

Council: Common Position on European Parliament's First Reading, 19/5/2008 19

Commission: Declaration on the Council's Common Position, 22/7/2008 19

European Parliament: Second Reading, 13/1/2009 20

Commission: Opinion on European Parliament's Second Reading, 16/2/2009 20

Council: Decision, 24/9/2009 21

European Parliament \& the Council: Adoption of Directive , 21/10/2009 21

Final Remarks $\quad 21$

Concluding Remarks 21

Epilogue $\quad 22$

References $\quad 25$

$\begin{array}{ll}\text { Annexes I-IV } & 29\end{array}$ 


\section{Prologue}

Aerial spraying has been banned by the European Union in 2009. A driving force underlying this ban has been a lobby campaign by the Europe chapter of the Pesticide Action Network (henceforth PAN). In 2000, PAN launched the Pesticide Use Reduction in Europe (PURE) campaign to lobby for binding EU legislation to reduce pesticide use. Campaign instruments included writing a draft Directive and an Explanatory Memorandum detailing the "factual and scientific rationale for reducing pesticide use". The campaign was supported by 92 signatories from $30 \mathrm{EU}$ countries, representing various interest groups, including trade unions and environment, food, public health, consumers, and farmer movements. This broad support from interest groups contributed considerably to the campaign's effect at EU level. PAN also reported to have gained the support from members of the European Parliament for many elements in their draft Directive.

Evidence for increasing exposure to- and adverse effects of pesticides had been growing, and the European Union's Fifth Environment Action Programme had "promised much but delivered very little" (PAN PURE campaign page). National regulations of Member States on pesticide use varied greatly; with regard to aerial spraying between a total ban, ban with exceptions, severe restrictions, no restrictions, and no regulation at all (see the BiPro Impact Assessments, 2004). According to PAN, several Member States had successfully introduced national pesticide use reduction programmes in the 1980 and 1990s, indicating that EU wide legislation was feasible.

PAN's draft Directive of the PURE campaign outlined a set of measures to achieve a more sustainable use of pesticides, including use reduction targets, making IPM mandatory, promoting organic farming, eliminating unsafe application practices such as aerial spraying, and minimum requirements for pesticide dealers and operators. ${ }^{2}$ In PAN's draft Directive, aerial spraying was to be prohibited altogether since it was considered an 'unsafe pesticide practice'. The specific section of the draft Directive further specified the need for minimum technical standards for application equipment, preparation and cleaning thereof, and minimum requirements for storage of pesticides and equipment.

The EU's final Directive similarly outlines a comprehensive programme that covers the diverse aspects of pesticide use. Its chapters address training, sales of pesticides, information and awareness-raising; pesticide application equipment; specific practices and uses; and indicators, reporting and information exchange. Aerial Spraying is covered in Article 9 of the chapter on specific practices and uses, which further discusses information to the public, the protection of aquatic environments and drinking water, reducing risks and uses in specific areas, handling and storage of pesticides and packaging, and integrated pest management.

The measure on aerial spraying, and the developments of the law making process outlined in this report, should therefore be acknowledged in the context of this comprehensive programme. According to PAN Europe (telephone interview with a PAN representative), the Directive's most important measures included the implementation of Integrated Pest

\footnotetext{
${ }^{1}$ PAN PURE campaign page: www.pan-europe.info/old/Archive/PURE/pure_campaign.htm (Retrieved 27 November 2018).

2 PAN Europe (2002) Suggested text for a Directive of the European Parliament and of the Council on measures for reduction of use and of impacts to health and environment from pesticides. PAN UK: London.
} 
Management, priority given to non-chemical alternatives, minimisation and prohibition of pesticide use in specific areas, and the establishment of appropriately-sized buffer zones.

The study for this report was part of a long term research programme on societal influence on the formulation of pesticide risk regulation. In this programme, we have studied the role of social movements (Nikol and Jansen, 2019; Barraza et al. 2013), businesses (Jansen, 2017), certifications (Jansen, 2004), neoliberalization (Toleubayev et al., 2011), and international conventions (Jansen and Dubois, 2014). Where most of these studies use ethnographic approaches and zoom in on underlying relationships and social dynamics, this report limits itself to a straightforward description of the different steps in which the European Union Directive, in particular its general ban on aerial spraying, evolved into its current form. 


\section{Introduction}

On 21 October 2009 the European Parliament and the Council adopted a general ban on aerial spraying of pesticides. ${ }^{3}$ With this Directive, the air-borne application of pesticides is only permitted in special cases within the territory of the European Union (EU). ${ }^{4}$ The ban is part of a broader environmental action plan to achieve a sustainable use of pesticides to minimize negative effects for human and environmental health. ${ }^{5}$ The intention to provide for stricter regulation of pesticide use had been officially codified by the European Parliament and Council in the Fifth Environment Action Programme (EAP) approved on 1 February $1993 .{ }^{6}$ Years of stakeholders consultation and negotiations followed and eventually resulted in "Directive 2009/128/EC of the European Parliament and of the Council of 21 October 2009 establishing a framework for Community action to achieve the sustainable use of pesticides". In this policymaking process, some of the most controversial debates revolved around the ban on aerial spraying. ${ }^{7}$ Opinions of stakeholders and views between the EU institutions differed substantially with respect to the stringency of the ban. ${ }^{8}$ This report further explores the controversy of the aerial spraying ban and its development by describing the entire policy-making process, from the adoption of the Fifth Environment Action Programme to the introduction of the ban in 2009.

The remainder of this report is structured as follows. Firstly, the contents of the Fifth and Sixth Environment Action Programme are briefly addressed. The Fifth EAP outlines the role of pesticides in environmental concerns and the need to address them, while the Sixth EAP points at the need for a thematic strategy on aerial spraying, specifying what it should address, and emphasising the importance of the participation of environmental NGOs in a dialogic process. Secondly, the first proposal from the European Commission for specific measures, including a general aerial spraying ban, to minimize the hazards to human health and the environment is discussed. This is the first time general ban is mentioned. Thirdly, this report sets out the consultation rounds that followed the publication of the first proposal. It observes a strong division of opinions and delays in the procedure. Fourthly, the Commission's impact assessment and the draft directive of 2006 are presented. It is argued here that the originally proposed policy measures changed little, though were formulated a bit weaker. Finally, the report describes the co-decision procedure of the EU during which the European Parliament and Council agreed on the contents and joint text of the final Directive. Proposed policy measure changed considerably, mainly because conditions to handle derogation requests were tightened by the EP, which gave priority to protect human health and environment.

\section{Environment Action Programmes}

The EU devises the longer-term Environment Action Programmes to guide its environmental policy and to inform various legislative measures to address environmental concerns, such as

\footnotetext{
3 Art. 9(1), Directive 2009/128/EC [21 October 2009] (See Annex I for Directive).

4 Art. 9(2), Directive 2009/128/EC [21 October 2009].

5 Art. 1, Directive 2009/128/EC [21 October 2009].

${ }^{6}$ Fifth Environment Action Programme [1 February 1993] at page 38.

7 European Commission, SEC (2006) 894 [12 July 2007] at page 192.

${ }^{8}$ European Commission, SEC (2006) 894 [12 July 2007] at page 194.
} 
degradation and pollution. ${ }^{9}$ This section describes the two Environment Action Programs that effected the 2009 EU Directive on the sustainable use of pesticides, which effectively banned aerial spraying: the Fifth Environment Action Programme (1993-2000) and the Sixth Environment Action Programme (2002-2010).

\section{Fifth Environment Action Programme, 1993-2000}

The Fifth Environment Action Programme differed from previous versions as it set longer term objectives and took a more global approach. ${ }^{10}$ It aimed to address a wide range of environmental concerns, such as climate change, acidification, water pollution, soil degradation and erosion, and waste management. ${ }^{11}$ On the risk of pesticides, the Environment Action Programme noted that the "systematic use of plant protection products has led to a relative resistance in parasites increasing the frequency and the costs of subsequent treatments and causing additional soil and water pollution problems"12. To minimize the pesticide risks, the Action Programme contained a target to significantly reduce "pesticide use per unit of land under production and conversion of farmers to methods of integrated pest management control, at least in all areas of importance for nature conservation". ${ }^{13}$ Such a reduction should, amongst others, be achieved through regulation and better control of sales and use of pesticides. ${ }^{14}$

To evaluate and further develop strategies and the framework for pesticide regulation, the Commission, launched a study in 1992, in collaboration with the Dutch authorities. ${ }^{15}$ This resulted in two workshops, held in June 1994 and May 1998, involving representatives of all Member States and other stakeholders, such as farmers, industry, and environmental and consumer groups. ${ }^{16}$ The second workshop concluded in the participants' joint acknowledgement for the "need for additional European Community plant protection products risk reduction policy instruments". ${ }^{17}$ Moreover, while a general ban on aerial spraying was not explicitly discussed in the workshop, the possibility of implementing area-based bans on pesticide use was considered. It was concluded that "area-based bans of pesticide use may be needed for specifically vulnerable areas. However, this is a complex issue and more information about the interaction of various factors is needed. It must be kept in mind that such bans are a matter of subsidiarity in the European Union". ${ }^{18}$

Shortly after, the European Parliament and the Council approved a revision of the Fifth Environment Action Programme, which further specified the need to regulate pesticide use in greater detail. It asked for the development of an "integrated strategy to reduce the

\footnotetext{
9 European Commission Environment Webpage, http://ec.europa.eu/environment/action-programme/ (retrieved 4 May 2016).

${ }^{10}$ Archives European Commission Webpage, http://ec.europa.eu/environment/archives/action-programme/5th.htm (retrieved 29 April 2016).

${ }^{11}$ Fifth Environment Action Programme [1 February 1993] at page 24.

${ }^{12}$ Fifth Environment Action Programme [1 February 1993] at page 35.

${ }^{13}$ Fifth Environment Action Programme [1 February 1993] at page 38.

${ }^{14}$ Fifth Environment Action Programme [1 February 1993] at page 38.

15 European Commission, SEC (2006) 894 [12 July 2007] at page 6.

${ }^{16}$ European Commission, SEC (2006) 894 [12 July 2007] at page 6.

${ }_{17}$ Proceedings of the Second Workshop on a framework for the Sustainable Use of Plant Protection Products in the European Union [May 1998] at page 46.

${ }^{18}$ Proceedings of the Second Workshop on a framework for the Sustainable Use of Plant Protection Products in the European Union [May 1998] at page 44.
} 
risks to health and the environment from the use of plants protection products and pesticides, including more detailed provisions on the distribution and sales of these substances and restrictions on use and, where appropriate, substitution of the most dangerous plant protection products and pesticides". ${ }^{19}$ Moreover, in relation to the management of risks and accidents, the sustainable use of pesticides should be achieved by "developing further measures in the area of agricultural and non-agricultural pesticides". ${ }^{20}$ The revision also asked for a global assessment of the implementation of the Action Programme, which eventually became a major building block of the Sixth Environment Action Programme presented by the Commission in 2001. ${ }^{21}$

\section{Sixth Environment Action Programme, 2002-2010}

On 24 January 2001 the Commission adopted the Communication on the Sixth Environment Action Programme. ${ }^{22}$ The eventual Environment Action Programme was approved by the European Parliament and the Council on 22 July 2002 and became effective immediately.23 As one of its priority areas for action, the Environment Action Programme asked for the sustainable use of pesticides to minimize negative impacts for human health and the environment. ${ }^{24}$ In specific, the Action Programme clarified that the reduction of pesticide risks should be pursued through the following actions ${ }^{25}$ :

1. Full implementation and review of the effectiveness of the applicable legal framework in order to ensure a high level of protection, when amended. This revision might include, where appropriate, comparative assessment and the development of Community authorization procedures for placing on the market;

2. A thematic strategy on the sustainable use of pesticides that addresses:

(i) minimizing the hazards and risks to health and environment from the use of pesticides;

(ii) improved controls on the use and distribution of pesticides;

(iii) reducing the levels of harmful active substances including through substituting the most dangerous with safer, including non-chemical, alternatives;

(iv) encouragement of the use of low input or pesticide free cultivation among others through raising users' awareness, promoting the use of codes of good practices, and promoting consideration of the possible application of financial instruments;

(v) a transparent system for reporting and monitoring progress made in fulfilling the objectives of the strategy including the development of suitable indicators;

\footnotetext{
${ }^{19}$ Art. 2(1)(d), Fifth Environment Action Programme (revised) [28 September 1998].

${ }^{20}$ Art. 11(7)(b), Fifth Environment Action Programme (revised) [28 September 1998].

${ }^{21}$ Archives European Commission Webpage, http://ec.europa.eu/environment/archives/actionprogramme/5th.htm (5 May 2016).

${ }^{22}$ European Commission, COM (2001) o031 final [24 January 2001].

${ }^{23}$ Sixth Environment Action Programme [22 July 2002].

${ }^{24}$ Art. 7(1), Sixth Environment Action Programme [22 July 2002].

${ }^{25}$ Art. 7(1)(c), Sixth Environment Action Programme [22 July 2002].
} 
The second action, outlining the development of a thematic strategy on the sustainable use of pesticides, was part of a broader goal to implement a total of seven thematic strategies. These strategies set long-term objectives for specific environmental themes, such as air pollution, soil protection and the urban environment. ${ }^{26}$ The Action Programme further specified that the development of these thematic strategies should be based on "general rules and principles of good governance within which stakeholders are widely and extensively consulted at all stages to facilitate the most effective choices for the best results for the environment and sustainable development in regard to the measures to be proposed". ${ }^{27}$ In particular, environmental NGOs should be encouraged to participate in the dialogue to develop environmental policy. ${ }^{28}$ Moreover, the Sixth Environment Action Programme stated that preference is given to the integration of new measures into existing policies and legislation. Only when this is not possible new legislation or other policy instruments should be proposed. 29

It was the development of this thematic strategy on the sustainable use of pesticides that eventually resulted in the Directive of 21 October 2009. On 1 July 2002 the Commission presented its first proposal for the Thematic Strategy on the Sustainable Use of Pesticides. ${ }^{30}$ In this communication the general ban on the aerial spraying of pesticides was mentioned for the first time.

\section{First Proposal for a Thematic Strategy on the Sustainable Use of Pesticides, I July 2002}

On 1 July 2002 the ban on aerial spraying of pesticides is officially proposed by the European Commission in its communication on a thematic strategy on the sustainable use of pesticides to the European Parliament, the Council, and the Economic and Social Committee. ${ }^{31}$ This communication contained several possible measures that could become part of the final Thematic Strategy, and also which measures the Commission of would prefer to implement. ${ }^{32}$ These preferences were based on studies mandated by the Commission on the use, benefits, and risks of pesticides; the numerous links between the Thematic Strategy and other EU policies that were already in place, and; the policies and initiatives that were already effective in some Member-States but not yet coordinated within the EU.33 The prohibition of aerial spraying of pesticides is first mentioned in the communication's section on national initiatives contributing to pesticide risk reduction. ${ }^{34}$ The "prohibition of aerial spraying for targeted protection of sensitive species and habitats, and protection of waters in general" had been identified as one of the measures addressing pesticide risks ${ }^{35}$ in a study ${ }^{36}$ on the

\footnotetext{
${ }^{26}$ European Commission, COM (2001) o031 final [24 January 2001] at page 6.

${ }^{27}$ Art. 10(a), Sixth Environment Action Programme [22 July 2002].

${ }^{28}$ Art. 10(b), Sixth Environment Action Programme [22 July 2002].

29 Art. 3, Sixth Environment Action Programme [22 July 2002].

$3^{\circ}$ European Commission, COM (2002) 349 final [1 July 2002].

${ }^{31}$ European Commission, COM (2002) 349 final [1 July 2002] at page 30.

${ }^{22}$ European Commission, COM (2002) 349 final [1 July 2002] at page 5.

33 European Commission, COM (2002) 349 final [1 July 2002] at page 4.

34 European Commission, COM (2002) 349 final [1 July 2002] at page 22.

35 European Commission, COM (2002) 349 final [1 July 2002] at page 22.

${ }^{36}$ Oppenheimer, Wolff \& Donnelly [1998].
} 
development of future EU policies on pesticides covering six Member States. The respective Member States had introduced the prohibition to address, amongst others, contamination of surface water or marine environments; effects of exposure to residues in water, soil and air, and; specific adverse effects on the ecology, e.g., non-target species. ${ }^{37}$

In line with the first goal of the Thematic Strategy on the sustainable use of pesticides, namely to minimize the hazards and risks to health and the environment from the use of pesticides, the Commission proposed a general ban on aerial spraying as preferred policy measure..$^{8}$ The Commission further clarified that "specific derogation may be given by the national authorities of the Member States if aerial spraying presents clear advantages and also environmental benefits compared to other spraying methods". 39 The Commission's proposal for a general ban is, however, only the first step towards the final legislation. The Commission stated that one of the main purposes of the communication was to launch a broad consultation involving all stakeholders, such as farmers, environmental and consumer groups, industry, and other social partners and public authorities. ${ }^{40}$ Moreover, the opinion of the EU institutions should also be considered. It was estimated that after the conclusion of the consultation process, the Commission would further specify the proposed measures in the course of 2003 and submit the proposal for approval to the Council and the European Parliament at the beginning of 2004. ${ }^{41}$ The next section will further elaborate on the consultation sessions that followed.

\section{Consultations following Commission's First Proposal, 2002-2005}

Following the Commission's first proposal for substantive measures to minimize the risks of pesticides to human health and the environment, the Commission organized various consultation rounds. The results of these consultations informed the Commission Services' preparation of an Extended Impact Assessment to identify the economic, social, health and environmental impacts of the measures proposed in Thematic Strategy of 2002.42 The outcomes were also used to further refine the 2002 Thematic Strategy, which resulted in the adoption of a draft directive by the Commission on 12 July 2006.43 This section describes the consultation rounds that were organized by the Commission in the period 2002-2005, including the collection of comments from stakeholders and EU institutions, the organisation of expert meetings, and the commission of an external consultancy study (BiPro).

\section{Consultations regarding Commission's First Proposal, 2002-2003}

The first step of the consultation exercise consisted of collecting opinions from stakeholders and EU institutions on the Commission's proposal of 1 July 2002. First, a stakeholders' conference was organized in November 2002. Second, all stakeholders were invited to react on the proposal in writing before November 2002. And finally, the European Parliament, the

\footnotetext{
37 European Commission, COM (2002) 349 final [1 July 2002] at page 22.

$3^{8}$ European Commission, COM (2002) 349 final [1 July 2002] at page 30.

39 European Commission, COM (2002) 349 final [1 July 2002] at page 30.

$4^{\circ}$ European Commission, COM (2002) 349 final [1 July 2002] at page 5.

${ }^{41}$ European Commission, COM (2002) 349 final [1 July 2002] at page 5.

${ }^{42}$ European Commission, SEC (2006) 894 [12 July 2007] at page 16.

${ }^{43}$ European Commission, COM (2006) 373 final [12 July 2006] at page 5.
} 
Council and the European Economic and Social Committee were kindly requested to comment on the measures proposed by the Commission. This section describes the results of these consultation procedures with respect to the measures of a general ban on aerial spraying.

\section{Stakeholders' Conference, 4 November 2002}

The stakeholders' conference on 4 November 2002 consisted of plenary sessions involving all participants and three separate working groups on the topics of water resources, integrated crop management, and national plans for hazard, risk, and dependence reduction. ${ }^{44}$ During the conference the issue of the ban on aerial spraying was not separately discussed (or, was not a separate agenda point). Still, the various stakeholders pointed out their opinions about bans on pesticides use and application methods in general without reaching a joint conclusion.45 This exchange of views on pesticide bans illustrates the strong division of opinions that also arose when the specific ban on aerial spraying was further discussed in the course of the consultation procedures. For example, Mr. Stuart Rutherford from the European Crop Protection Association (ECPA), representing industry, concluded that " $E U$ wide bans are not favoured as a solution". ${ }^{6}$ Contrary to the ECPA, Mr. Hans Muilerman from the Pesticide Action Network, representing environmental NGOs, argued that the reduction of pesticide use is difficult and requires the combination of bans and better practices and management. ${ }^{47}$ The results of the second consultation method sheds further light on the controversy surrounding the general ban on aerial spraying.

\section{Stakeholders' written reactions to Commission's First Proposal, 2002}

As soon as the Commission had presented its communication on 1 July 2002, all stakeholders were invited to react to the proposed measures in writing before November 2002..$^{8}$ In total, more than 150 contributions were submitted covering a wide range of stakeholders such as industry, NGOs, farmers, academics, public authorities, and consumer groups. ${ }^{49}$ With respect to the proposal for a general ban on aerial spraying, the Commission concluded that the opinions were strongly divided..$^{\circ}$ In general, industry and professionals, such as farmers and helicopter companies, strongly opposed a strict ban on aerial spraying. ${ }^{51}$ On the other hand, environmental groups and individuals, such as citizens and academics, supported the general ban on aerial spraying and even insisted on eliminating the possibility for derogation under exceptional circumstances. ${ }^{52}$ It should be noted, however, that disagreement also existed within

\footnotetext{
44 Proceedings of the Stakeholders' Conference on the Development of a Thematic Strategy on the Sustainable Use of Pesticides [November 2004] at page 2.

45 Proceedings of the Stakeholders' Conference on the Development of a Thematic Strategy on the Sustainable Use of Pesticides [November 2004] at pages 16, 17, 18 \& 20.

${ }^{46}$ Proceedings of the Stakeholders' Conference on the Development of a Thematic Strategy on the Sustainable Use of Pesticides [November 2004] at page 17.

47 Proceedings of the Stakeholders' Conference on the Development of a Thematic Strategy on the Sustainable Use of Pesticides [November 2004] at page 20.

${ }^{48}$ Archives European Commission, http://ec.europa.eu/environment/archives/ppps/1st_step_consul.htm (retrieved 5 May 2016).

49 European Communities [2007] at page 13.

${ }^{50}$ European Commission, SEC (2006) 894 [12 July 2007] at page 194.

${ }^{51}$ European Commission, SEC (2006) 894 [12 July 2007] at page 194.

${ }^{52}$ European Commission, SEC (2006) 894 [12 July 2007] at page 194.
} 
the different stakeholders' groups, for example between scientists, farmers and industrial groups. ${ }^{53}$ The following quotes taken from the written reactions illustrate the diverging positions with respect to the proposed ban:

"The Crop Protection Association is opposed to a general ban of aerial spraying. It is important to recognise that there are some areas such as forests of slopes where aerial spraying cannot be replaced by other techniques of crop protection using wheeled sprayers. Alternative such as handheld application may not be suitable or cost effective" ${ }^{\prime 4}$ - Crop Protection Association UK

"Farmer will lose the means to carry out treatments whose effectiveness has been confirmed repeatedly. They will be put into a particular difficult situation which will jeopardize a share of their activities. A ban on aerial spraying will mean the death of those enterprises specialized in the air-borne application of pesticides with all the social consequences one can imagine" 55 (translated from French) - Groupement Français de l'Hélicoptère

"I support a general ban on aerial spraying. I do not support the proposal that "specific derogation may be given by member states if aerial spraying presents clear advantages and also environmental benefits", unless there are very specific requirements to ensure that there is no possibility whatsoever of spray drift reaching any local resident or people walking nearby"56 - Dr. Howard, Head of Research, Developmental Toxico-Pathology Research Group, University of Liverpool

"PAN Europe and the EEB support a total ban on aerial spraying with no possibility of derogation, which could open the door to possible abuse"57 - Pesticides Action Network Europe E the European Environmental Bureau

\section{Comments from EU Institutions, 2003}

As a final step, the Commission invited the European Parliament, the Council, and the European Economic and Social Committee to comment on the proposed measures. Whereas the Council 58 and the Economic and Social Committee ${ }^{59}$ did not address the ban on aerial spraying, the European Parliament expressed its full support for a general ban on aerial spraying. ${ }^{60}$

\footnotetext{
53 See, for example, Association of Users and Distributors of Agrochemicals in Europe [2002] at page 13 (representing industry/growers: in favour of ban).

${ }^{54}$ Crop Protection Association UK Ltd [2002] at page 5.

55 Groupement Français de l'Hélicoptère [2003] at page 1.

${ }^{5}$ Howard [2002] at page 2.

57 Pesticides Action Network Europe \& European Environmental Bureau [2002] at page 4.

${ }^{58}$ European Council, 15101/o2 [2002].

59 European Economic and Social Committee, NAT/156 [2003].

6o European Parliament, $\mathrm{P}_{5}$ TA(2003) 0128 [2003] para. 7.
} 


\section{Expert Meetings, 2003-2004}

In addition to the written reactions to the Commission's communication, the Directorate General Environment of the European Commission organized five expert meetings involving stakeholders and representatives of the Member States on topics related to the Thematic Strategy, namely: Compliance (10 March 2003); Aerial Spraying (31 March 2004); Sprayers (27 April 2004), Indicators (24 May 2004), and; Collection of Empty Packaging (22 June 2004). ${ }^{61}$ This section briefly discusses the outcomes of the expert meeting on Aerial Spraying on 31 March 2004 .

\section{Expert Meeting on Aerial Spraying, 31 March 2004}

The purpose of the expert meeting was to further discuss the Commission's proposal for a general ban on aerial spraying and to collectively examine the preliminary results of an external consultancy ${ }^{62}$ commissioned by the European Commission, which will be discussed below. ${ }^{63}$ The competent authorities of the EU Member States, NGOs, pesticide manufacturers and their associations, aircraft manufacturers, and farmers and their professional unions were represented. ${ }^{6}$

The representatives of eight EU Member States were invited to present on the current regulatory and practical situation regarding the aerial spraying of pesticides within their territory. Out of the eight Member States, two States had already adopted a ban on aerial spraying. ${ }^{65}$ Moreover, all eight Member States had put in place some restrictive measures on the air-borne application of pesticides, ranging from aerial spraying restrictions on crops and pests to mandatory safety measures that need to be taken when aerial spraying is executed. ${ }^{66}$

The other stakeholders were also requested to give a brief presentation outlining their views on a regulatory framework for aerial spraying. Again, the disagreement between the various groups is clearly illustrated by the exchange of views during this expert meeting. To start with, the manufacturers of planes and helicopters and the aerial spraying applicators argued that the air-borne application method of pesticides is not per se dangerous if correctly managed and implemented. They advocated for a flexible regulatory process that would tolerate the new uses of aerial spraying in the future. Furthermore, they highlighted several advantages of aerial spraying, such as its economic efficiency and its low fuel consumption compared to ground application. ${ }^{67}$

The Pesticide Action Network, representing environmental NGOs, challenged the views of aviation industry and aerial spraying applicators by stating that general statements on the advantages of aerial spraying cannot possibly be made. It stated that it should be further assessed how and to what extent aerial spraying could lead to pesticide use reduction and

\footnotetext{
${ }^{61}$ Archives European Commission, http://ec.europa.eu/environment/archives/ppps/2nd_step_tech.htm (retrieved 5 May 2016).

62 BiPRO [February 2004].

63 Archives European Commission, http://ec.europa.eu/environment/archives/ppps/2nd_step_tech.htm (retrieved 2 May 2015).

${ }^{64}$ Directorate-General Environment of the European Commission [2004] at page 1.

${ }_{55}$ Directorate-General Environment of the European Commission [2004] at page 2-3. (Ban on aerial spraying: Austria \& Belgium (only by planes), No ban on aerial spraying: Germany, France, United Kingdom, Greece, Spain, Portugal).

${ }^{66}$ Directorate-General Environment of the European Commission [2004] at page 2-3.

${ }^{67}$ Directorate-General Environment of the European Commission [2004] at page 4.
} 
whether it could truly improve the safety of the operators and bystanders. However, they seemed to be open to reconsider their original position to implement a total ban on aerial spraying without any derogation possibilities. ${ }^{68}$

Finally, the European Crop Protection Association and the International Biocontrol Manufacturers Associations together with pesticide manufacturers (Bayer, BASF, Valent) stated that they would support restrictions on aerial spraying, but did require the possibility of derogation in those cases where no other viable alternatives were available or where it provided clear environmental benefits compared to other application methods. They further specified that in order to determine the most suitable application method, factors such as height of the crop, topography, and access to the crop should be taken into account. ${ }^{69}$

Based on the input from EU Member States and the different stakeholder groups, the Directorate-General Environment of the Commission drew some tentative conclusions. The Directorate-General noted that the best solution for aerial spraying would be to take restrictions rather than a general ban as starting point..$^{70}$ Moreover, the Directorate-General stated that rulesetting at national level should be preferred over an EU wide regulatory framework..$^{1}$

\section{External Consultancy, 2004-2005}

As briefly mentioned in the previous section, the Commission mandated Beratungsgesellschaft für integrierte Problemlösungen (BiPRO) to conduct an external impact assessment of specific measures to be part of the Thematic Strategy on the Sustainable Use of Pesticides. ${ }^{72}$ The results from BiPRO's study would, first of all, inform the extended impact assessment developed by the Commission Services itself. ${ }^{73}$ Second, the impact assessment provided for another consultation opportunity involving various stakeholders. ${ }^{74}$ After the publication of BiPRO's impact assessment, stakeholders were invited to submit their reactions in writing to the European Commission before 31 January 2005.75

This section first discusses the results of BiPRO's impact assessment of the proposed ban on aerial spraying, and secondly, briefly addresses the written statements of the respective stakeholders.

\section{BiPRO's Impact Assessment, October 2004}

As mandated by the Commission, BiPRO carried out a study to determine the economic, social and environmental impacts of the various policy options of the Thematic Strategy on the sustainable use of pesticides. In total, BiPRO analysed eight issue topics including aerial

\footnotetext{
${ }^{68}$ Directorate-General Environment of the European Commission [2004] at page 4.

69 Directorate-General Environment of the European Commission [2004] at page 4.

$7^{\circ 0}$ Directorate-General Environment of the European Commission [2004] at page 5 .

${ }^{71}$ Directorate-General Environment of the European Commission [2004] at page 5 .

${ }^{72}$ BiPRO [October 2004] at page 8.

73 European Commission, SEC (2006) 894 [12 July 2007] at page 5.

${ }^{74}$ European Commission, SEC (2006) 894 [12 July 2007] at page 5.

${ }^{75}$ Archives European Commission, http://ec.europa.eu/environment/archives/ppps/2nd_step_study.htm (retrieved 2 May 2016).
} 
spraying. Besides a legally binding ban on aerial spraying with derogation possibilities as proposed by the Commission in 2002, BiPRO studied four other policy options: ${ }^{76}$

1. Non-binding recommendations by the Commission of severe restrictions or ban of aerial spraying according to the national rules of the individual EU Member States.

2. Introduction of appropriate financial instruments (e.g. taxes, levies, fees) to increase the cost of aerial spraying significantly in order to reduce aerial spraying without further restrictions or a ban.

3. Legally binding minimum requirements that have to be fulfilled for the application of pesticides by aerial spraying (e.g. only pilots trained and certified for aerial spraying are allowed to practice; checked and certified application material has to be used; announcement to authorities in advance).

4. No action.

The third policy option had been developed as response to the outcomes of the expert meeting on aerial spraying in March 2004. As suggested by the Directorate-General, this third option has restrictions on aerial spraying rather than a general ban as starting point. Furthermore, this option would also grant more flexibility to the Member States with respect to the scope of the requirements. ${ }^{77}$

Based on three case studies on the use of aerial spraying, in France (vineyards), Spain (olive trees), and Germany (forests), and on the basis of general data on aerial spraying, BiPRO determined the impacts of the five policy options on farmers, aerial and ground spraying companies, public authorities, and on the producers of ground and aerial spraying equipment. ${ }^{78}$ Moreover, it assessed the effects of the policy measures on the environment, health, food production, and plant protection issues in general. ${ }^{79}$

As a result of this analysis, BiPRO dismissed the introduction of a legal ban on aerial spraying as preferred policy option. ${ }^{80}$ According to BiPRO the ban would lead to significant economic deficits due to yield losses and higher costs for alternative treatments. Moreover, no or only a few aerial spraying companies would survive the ban resulting in a significant loss of jobs. On the other hand, ground spraying and equipment companies would experience clear positive economic and social impacts due to an increase in the demand for the ground spraying of pesticides. Additionally, it was estimated that a ban would have negative health impacts as more labour and longer operating times are necessary when using alternative forms of treatment, which will increase applicators' exposure to pesticides. BiPRO did not provide for any predictions on the health impacts for the wider public. On a positive note, BiPRO concluded that the ban would bring about positive effects on the environment in areas where aerial spraying was common practice. In relation to public authorities, BiPRO notes a positive change since a ban would reduce the administrative efforts as control and permitting activities will decrease or cease completely. ${ }^{81}$

\footnotetext{
${ }^{6}$ BiPRO [October 2004] at pages 66-67.

77 BiPRO [October 2004] at pages 66-68.

${ }^{78} \mathrm{BiPRO}$ [October 2004] at pages 110-111.

79 BiPRO [October 2004] at page 146.

${ }^{80}$ BiPRO [October 2004] at pages 349-350.

${ }^{81}$ BiPRO [October 2004] at page 147.
} 
In conclusion, BiPRO recommended the third policy option of legally binding minimum requirements, as suggested by the Directorate-General on the basis of the expert meeting in March 2004. ${ }^{82}$ According to BiPRO, this policy option would positively impact the environment, since improper aerial spraying would be prohibited whereas proper aerial spraying would continue. Furthermore, it was estimated that this measure would positively affect operators' health since their exposure to pesticides would be reduced significantly. Moreover, this policy would have no significant adverse economic or social impacts ${ }^{83}$. All other policy options, including the ban on aerial spraying, are considered neutral with no clear positive or negative impacts. ${ }^{84}$

\section{Stakeholders' written reactions to BiPRO's Impact Assessment, 2005}

After the publication of BiPRO's impact assessment in October 2004, stakeholders were invited to react to the study before 31 January 2005. In total, 28 stakeholders submitted their written reactions to the Commission. ${ }^{85} \mathrm{~A}$ significant majority of these submissions expressed their approval of BiPRO's impact assessment. Generally, it can be stated that the representatives of industry, helicopter companies and users of aerial spraying (farmers) supported BiPRO's recommendation for legally binding requirements for the application of pesticides by aerial spraying rather than a general ban with derogation possibilities. ${ }^{86}$ Stakeholders that previously seemed to be open to ${ }^{87}$ or be strongly supportive of a legally binding ban now only expressed their support for BiPRO's recommendation. ${ }^{88}$ Furthermore, various submissions pointed out that national legislation on aerial spraying in their countries already sufficed to ensure safe airborne application of pesticides. Therefore, additional restrictions would not be applicable to their situation. ${ }^{89}$ Moreover, some of the reactions contained proposals to not pursue EU harmonization of aerial spraying regulation in all its aspects. Given the different "field" situations within the Member States it would be best to leave part of the rule-setting up to Member States. ${ }^{90}$

Those in favour of a general ban were less well represented in this consultation round. Only two out of the 28 reactions expressed their disapproval of the policy option of legally binding requirements and instead advocated for a total ban on aerial spraying. ${ }^{91}$

\footnotetext{
${ }^{82}$ BiPRO [October 2004] at page 349.

${ }^{83}$ BiPRO [October 2004] at page 349.

${ }^{84}$ BiPRO [October 2004] at pages 350-351.

${ }^{85}$ Archives European Commission, http://ec.europa.eu/environment/archives/ppps/2nd_step_react.htm (retrieved 3 May 2016).

${ }^{86}$ See, for example, European Association of Craft, Small and Medium-Sized Enterprises [2005] at pages 1-2; National Farmers Union UK Ltd [2005] at page 3; Crop Protection Association UK [2005] at page 1; German Helicopter Association [2005] at page 1.

${ }^{87}$ With the requirement that substantial derogation possibilities would be allowed.

${ }^{88}$ See, for example, Association of Users and Distributors of Agrochemicals in Europe [2005] at page 1. The submission states that "although reluctant, at first, to see the benefits of such a method of application, we have to come to see it is well-founded thanks to the argumentation put forward by the Groupement Français de l'Hélicoptère and testimony of users as the Chambre Syndicale du Peuplier de France. We therefore support the option of professional and regulated aerial spraying with helicopter [...]".

${ }^{89}$ See, for example, Crop Protection Association UK [2005] at page 1; Germany Helicopter Association [2005] at page 1.

9o See, for example, European Crop Protection Association [2005] at page 4.

${ }^{91}$ Pesticide Action Network Europe [2005] at pages 1-2; Association de Défense, d'Education et d'Information du Consommateur [2005] at page 1 .
} 
Interactive Policy Making Consultation, March-May 2005

After the conclusion of the consultation round about BiPRO's impact assessment, the Commission launched a final online consultation from March until May 2005. ${ }^{92}$ Under the heading of an Interactive Policy Making Consultation, a total of 1772 stakeholders responded to an online survey on the various policy options to be part of the Thematic Strategy on the sustainable use of pesticides. ${ }^{93}$ Interestingly, the question on aerial spraying did not include any reference to a legally binding ban. Instead it aimed to identify the preferred minimum requirements that should be covered by national regulations to ensure that aerial spraying would be carried out safely and carefully. ${ }^{94}$ To once again highlight the need for a ban on aerial spraying, several NGOs submitted additional letters advocating for such a ban. ${ }^{55}$ The overview below presents the answers to this question: ${ }^{96}$

In your opinion what minimum requirements should be covered by national regulations to ensure that aerial spraying is done carefully?

$\mathrm{N}^{*} \quad \%^{* *}$

Specific training and certification of pilots

1404

79.5

Restrictive list of "priority crops" for which aerial spraying will be maintained

Specific authorisation procedure for plant protection products applicable by aerial spraying

Prior informed consent procedure managed by local authorities with systematic assessment of the risks associated with the aerial spraying of specific plots of land

* Total number of positive responses (out of 1772)

** Percentage of positive responses

\section{Table 1. Online consultation on policy options}

\section{Final Remarks}

This section has described the different consultation rounds, which followed the publication of the Commission's first proposal, for specific measures to be part of the Thematic Strategy on

\footnotetext{
$9^{2}$ European Commission, SEC (2006) 894 [12 July 2007] at page 147.

93 European Commission, SEC (2006) 894 [12 July 2007] at page 206.

94 European Commission, SEC (2006) 894 [12 July 2007] at page 213.

95 European Commission, SEC (2006) 894 [12 July 2007] at page 206.

${ }^{96}$ European Commission, SEC (2006) 894 [12 July 2007] at page 213.
} 
the Sustainable Use of Pesticides. The opinions among stakeholders were strongly divided on the ban on aerial spraying. Generally, representatives of the industry, helicopter companies, and applicators (farmers) opposed to a general ban on aerial spraying. Environmental NGOs, consumer groups, and individuals, such as academics and citizens, were highly in favour of a general ban, if not a total ban. However, over the course of the consultation process - mainly following the Expert Meeting on March 2004 and BiPRO's impact assessment - pressure for a legally binding ban on aerial spraying seemed to have decreased even though environmental NGOs and consumer groups still insisted on a total ban on aerial spraying.

Furthermore, it can be concluded that at the end of the consultation rounds in 2005, the policy-making process on the sustainable use of pesticides had suffered substantial delays. According to the Commission's original schedule, the stakeholders' consultation should have ended in the course of 2003 so the Commission could have submitted its draft directive for approval to the Council and the European Parliament in the beginning of 2004. The Commission's final proposal, however, was only received by the Council and the European Parliament in July 2006.97 The next section elaborates on the Commission's second proposal for a Thematic Strategy which was accompanied by an Extended Impact Assessment conducted by the Commission Services itself.

\section{Second Proposal for a Thematic Strategy on the Sustainable Use of Pesticides, 12 July 2006}

As mentioned above, the consultations following the Commission's first proposal for a Thematic Strategy on the Sustainable Use of Pesticides were conducted to, first, inform the extended impact assessment of the Commission Services, and, secondly, to further refine the Commission's proposal for the specific measures of the Thematic Strategy. This section describes the main conclusions about the ban on aerial spraying of both the extended impact assessment and the draft directive as presented by the Commission to the Council and the European Parliament.

\section{Commission's Extended Impact Assessment, I 2 July 2006}

Much of the information presented in the Commission Services' impact assessment is directly taken from BiPRO's study and the results of the extensive consultation process..$^{8}$ This led to, more or less, the same conclusions about the impacts of the different policy measures that involved aerial spraying. ${ }^{99}$ However, the final recommendation for the measure to be part of the Thematic Strategy differed from BiPRO's conclusion. The Commission finally proposed to prohibit aerial spraying, but to allow derogations in situations where it can be proven that aerial spraying offers clear advantages, including environmental benefits, compared to other spraying methods, or where there are no other viable options. ${ }^{100}$ The Commission clarified that even though the terminology of a "ban" is preferred because of its strong political message, the actual

\footnotetext{
97 European Commission, COM (2006) 373 final [12 July 2006].

$9^{8}$ European Commission, SEC (2006) 894 [12 July 2007] at page 139.

99 European Commission, SEC (2006) 894 [12 July 2007] at page 146-149.

${ }^{100}$ European Commission, SEC (2006) 894 [12 July 2007] at page 180.
} 
implications of the regulation correspond more closely to BiPRO's recommendation for legally binding minimum requirements on the use of aerial spraying. ${ }^{101}$ These minimum requirements apply to derogations granted, to ensure the protection of the environment and to secure the health of residents and other bystanders. ${ }^{102}$ According to the Commission, allowing aerial spraying by way of derogation provides for the advantages of avoiding yield losses, higher costs for ground application, and the loss of turnover for aerial spraying companies. ${ }^{103}$

\section{Commission's Draft Directive, 12 July 2006}

Consistent with the Extended Impact Assessment the Commission proposed a general prohibition on aerial spraying with the possibility of derogation in its draft directive to the European Parliament and the Council. ${ }^{104}$ It further specified that the detailed requirements for derogation will not be adopted at the EU level, but at the level of the Member States. Member States were requested to report on these requirements to the Commission. ${ }^{105}$

\section{Final Remarks}

It can be concluded that after four years of consultation and impact analyses, the Commission's original position on the regulatory framework on aerial spraying has changed little. It started and ended with the same proposal of a general ban on aerial spraying with derogation possibilities. It is important to remark that the Commission had somewhat weakened the general ban by emphasizing the various benefits of allowing aerial spraying by way of derogation. Moreover, in its Extended Impact Assessment the Commission implied that the terminology of the ban was preferred more because of its political strength rather than its legal implications. Also, the Commission clarified that the implementation of the general ban would correspond more closely to BiPRO's recommendation for minimum user requirements of aerial spraying than to a strict legally binding ban with exceptions under highly exceptional circumstances. Additionally, the details of these requirements would be specified by the competent authorities of the Member States instead of the European Parliament and the Council.

After the submission of the Commission's final proposal, the official consultation process had come to an end. The policy-making process then proceeded to the next step: the Co-Decision Procedure of the European Parliament and the Council. The next section further discusses the internal decision-making of the EU with respect to the general ban on aerial spraying.

\footnotetext{
${ }^{101}$ European Commission, SEC (2006) 894 [12 July 2007] at page 180.

${ }^{102}$ European Commission, SEC (2006) 894 [12 July 2007] at page 180.

${ }^{103}$ European Commission, SEC (2006) 894 [12 July 2007] at page 181.

${ }^{104}$ Art. 9, Draft Directive as presented by the European Commission [12 July 2007] (See Annex II for Draft Directive).

105 European Commission, COM (2006) 373 final [12 July 2006] at page 11.
} 


\section{EU Co-Decision Procedure, 2006-2009}

This section describes the co-decision procedure on the Thematic Strategy on the Sustainable Use of Pesticides and in specific Article 9 specifying the measure of a general ban on aerial spraying. The co-decision procedure is based on the principle of parity and ensures that neither the European Parliament nor the Council may adopt new legislation without the other's consent. ${ }^{106}$ It consists of several readings and communications between the Parliament and the Council until both bodies have agreed on a joint text. ${ }^{107}$ First, the comments of the European Economic and Social Committee with respect to the aerial spraying ban will be discussed. ${ }^{108}$ The proposal was also sent to the Committee of Regions, but since the Committee did not comment on the aerial spraying ban, this document will not be discussed. ${ }^{109}$ Second, this section describes how the different readings by the European Parliament and the Council changed the Commission's proposal which eventually resulted in the Directive of 21 October 2009.

\section{European Economic and Social Committee, 14 March 2007}

The European Economic and Social Committee noted, first, that when introducing precautionary measures in sensitive context, such as the one on aerial spraying, a certain degree of subsidiarity should be secured. ${ }^{110}$ Second, the Committee expressed concerns that in those situations where aerial spraying should still be approved, these derogations should be very limited to avoid adverse effects on human health and the environment. To secure the greatest possible level of safety and professionalism among the operators, the public authorities of the Member States should rely on standardized risk assessment procedures to serve the systematic monitoring of safety and competence levels. ${ }^{11}$

\section{European Parliament: First Reading, 23 October 2007}

Before the European Parliament adopted the resolution on its first reading, it requested the Committee on Legal Affairs, the Committee on the Environment, Public Health, and Food Safety, the Committee on Industry, Research, and Energy, and the Committee on Agriculture and Rural Development to comment on the Commission's proposal for a draft directive. ${ }^{12}$ Taking into account these opinions, the European Parliament adopted its first reading on 23 October 2007. ${ }^{13}$ The amendments clearly show that the European Parliament attempted to

\footnotetext{
${ }^{106}$ Art. 294, TFEU [13 December 2007]. The 2007 Treaty of Lisbon -amending the Treaty on the European Union (TEU) and the Treaty establishing the European Community (Treaty on the Functioning of the European Union TFEU) - made the co-decision procedure the standard legislative procedure central to the European Community's decision-making system.

107 Additionally, the proposal may also be sent to the European Economic and Social Committee and/or the Committee of Regions so their views can also be taken into account. These two EU institutions will, however, have no vote in the adoption of the final act.

Archives European Commission, http://ec.europa.eu/codecision/stepbystep/diagram_en.htm (retrieved 3 May 2016).

${ }^{108}$ European Economic and Social Committee, 2007/C 161/15 [14 March 2007].

${ }^{109}$ Committee of Regions, 2007/C146/o6 [13 February 2007].

${ }^{110}$ European Economic and Social Committee, 2007/C 161/15 [14 March 2007] at para. 1.6.

${ }^{111}$ European Economic and Social Committee, 2007/C 161/15 [14 March 2007] at para. 4.1.4.

${ }^{112}$ European Parliament, P6_TA(2007) 0444 [23 October 2007].

${ }^{113}$ European Parliament, P6_TA(2007) 0444 [23 October 2007].
} 
further restrict the conditions for derogation from the aerial spraying ban. ${ }^{114}$ Even though it accepted that in certain situations and locations - particularly those in crisis - aerial spraying is an essential method of application, strict measures had to be implemented to minimise risks for human health and the environment. ${ }^{115}$ The Parliament aimed to realize a higher stringency of the ban by, first, amending the Commission's conditions and, second, laying down additional conditions for derogations. ${ }^{116}$ For example, it introduced a provision that prohibited the use of certain hazardous substances for aerial spraying in order to minimize pollution of aquatic environments. ${ }^{117}$ Additionally, in line with the opinion of the European Economic and Social Committee, the European Parliament introduced a provision on the monitoring responsibilities of public authorities of Member States. ${ }^{118}$ Also, the Parliament requested that the derogation records should be made available to the public and that operators would notify the authorities about the time of spraying and the amounts and types of pesticides used, so the public could be fully informed to better protect themselves against the risk of exposure. ${ }^{119}$

\section{Commission: Opinion on European Parliament's First Reading, 23 October 2007}

Even though the Commission does not have a vote in the final adoption of directives in the codecision procedure, it is mandated to present its position on the European Parliament's and the Council's amendments to the original proposal. ${ }^{200}$ On 23 October 2007, parallel to the European Parliament's resolution on its first reading, the Commission decided on its position on the respective amendments. The Commission fully accepted the addition that derogation records should be made available to the public. ${ }^{121}$ It approved in principle the suggestion to impose a monitoring responsibility on the public authorities of Member States given that the provision would be further clarified. The same applies to the requirement for operators to inform the authorities of the time of aerial spraying and the amount and types of pesticides applied. ${ }^{122}$ With respect to the additional minimum requirements for the use of aerial spraying, the Commission accepted the majority of the Parliament's contributions on the condition that it would be subject to wording improvement. The Commission did not approve of the obligation of prior notification and the requirement that the socio-economic and environmental benefits should outweigh the potential health risks for residents and bystanders. ${ }^{123}$ According to the

\footnotetext{
${ }^{114}$ See Annex III for all amendments by the European Parliament to the Commission's proposal.

${ }^{115}$ European Parliament, Final A6-0347/2007 [26 September 2007] at page 36.

${ }^{116}$ European Parliament, P6_TC1-COD(2006)0132 [23 October 2007].

${ }^{117}$ European Parliament, Final A6-0347/2007 [26 September 2007] at page 36.

${ }^{118}$ European Parliament, P6_TC1-COD(2006)o132 [23 October 2007].

${ }^{119}$ European Parliament, Final A6-0347/2007 [26 September 2007] at page 38.

${ }^{120}$ Archives European Commission, http://ec.europa.eu/codecision/stepbystep/diagram_en.htm (retrieved 3 May 2016).

${ }^{121}$ European Commission, Common Position on European Parliament's Amendments on 1st Reading [23 October 2007] at page 1.

${ }^{122}$ European Commission, Common Position on European Parliament's Amendments on 1st Reading [23 October 2007] at pages 1-2.

${ }^{123}$ European Commission, Common Position on European Parliament's Amendments on 1st Reading [23 October 2007] at page 3 .
} 
Commission these provisions either would have weakened the original proposal or would have been too difficult to implement. ${ }^{124}$

\section{Council: Common Position on European Parliament's First Reading, 19 May 2008}

On 18 September 2006 the Council held a public debate in which two Commission members further elaborated on the draft directive for the sustainable use of pesticides. ${ }^{125}$ In this same meeting, certain Member States identified a number of issues which had to be further examined. They included the varying needs of the individual Member States and ways to ensure that pesticides would still be available to minor crops. ${ }^{126}$ After this meeting, the Council further discussed the proposal behind closed doors and reached a political agreement on 17 December $2007 \cdot{ }^{127}$ It was, however, only on 18 May 2008 that the Council adopted its common position on the amendments to the original proposal by the European Parliament.

In the common position, the Council agreed with the Parliament's general approach to the issue of aerial spraying, in particular the provision on the monitoring of aerial spraying by Member States' public authorities. ${ }^{128}$ However, the Council rejected those amendments that risked the creation of excessive administrative burdens for the respective authorities. ${ }^{129}$ This meant that some of the additional conditions of derogations were refuted by the Council.

Commenting on the original proposal of the Commission, the Council specified that the products used must be approved on the basis of a specific risk assessment, which resembled the suggestion by the European Economic and Social Committee. The Council added that the companies providing the service of aerial spraying should be certified. ${ }^{130}$ It also introduced a provision on the transition period where the certificate system would not yet be in place. ${ }^{131}$ Additionally, it provided for the option of tacit approval of requests for derogations by the respective authorities after a certain period of time had elapsed. ${ }^{132}$ Lastly, it also agreed with the European Economic and Social Committee that a certain degree of subsidiarity should be granted since the Council increased the possibilities for Member States to further specify the details of the ban. ${ }^{133}$

\section{Commission: Declaration on the Council's Common Position, 22 July 2008}

On 22 July 2008 the Commission transmitted its declaration on the Council's Common Position to the European Parliament and to the Council so the second round of readings

\footnotetext{
${ }^{124}$ European Commission, Common Position on European Parliament's Amendments on 1st Reading [23 October 2007] at page 3.

125 Press Release C/06/251 [18 September 2008].

${ }^{126}$ Press Release C/06/251 [18 September 2008].

${ }^{127}$ EUR-Lex Webpage, http://eur-lex.europa.eu/procedure/EN/194492 (retrieved 4 May 2016); Press Release C/o7/294 [17-19 December 2007].

${ }^{128}$ Council, Common Position (EC) No. 21/2008 [19 May 2008] at page 16. (See Annex IV for common position and changes to Commission's Proposal and European Parliament's amendments).

129 Council, Common Position (EC) No. 21/2008 [19 May 2008] at page 16.

${ }^{130}$ Council, Common Position (EC) No. 21/2008 [19 May 2008] at page 6.

${ }^{131}$ Council, Common Position (EC) No. 21/2008 [19 May 2008] at page 6.

${ }^{132}$ Council, Common Position (EC) No. 21/2008 [19 May 2008] at page 16.

133 Council, Common Position (EC) No. 21/2008 [19 May 2008] at page 6.
} 
could commence. ${ }^{134}$ The Commission accepted the Council's proposals for the need to carry out a specific risk assessment for the approval of products; the introduction of a certification system for the companies responsible for aerial spraying, and; the establishment of a transition period where the certification procedures would not yet be in place. ${ }^{135}$ The Commission rejected the possibility for tacit approval of requests for derogations after a certain period has elapsed since this would weaken the original proposal. ${ }^{136}$ Moreover, the Commission reaffirmed its support for certain amendments by the European Parliament that had not been incorporated in the Council's common position, such as the publication of derogation records and the requirement for operators to notify details on the time of spraying and the types of pesticides used. ${ }^{137}$

\section{European Parliament: Second Reading, 13 January 2009}

On 13 January 2009 the European Parliament adopted its conclusion on its second reading. Prior to January 2009 the European Parliament and the Council had engaged in negotiations to reach an agreement on the text of the final directive. ${ }^{138}$ Thereby, the position of the European Parliament in its second reading also reflected the wishes of the Council.139 The European Parliament - based on recommendations made by the Committee on the Environment, Public Health and Food Safety - insisted that the following provisions would be part of the final directive: the aircraft must be equipped with the best available technology to reduce spray drift; the notification of professional operators wishing to apply pesticides by aerial spraying, should include information on the time of spraying, and the amount and the types of pesticides used, and; the derogation records should be made available to the public. ${ }^{140}$ Furthermore, the European Parliament rejected - in agreement with the Commission - the Council's proposal for the option of tacit approval for aerial spraying requests after a specific time period had elapsed. ${ }^{141}$

\section{Commission: Opinion on European Parliament's Second Reading, I 6 February 2009}

On 16 February 2009 the Commission reviewed the conclusions of the European Parliament's second reading. ${ }^{122}$ It noted that the amendments with respect to aerial spraying mainly concerned the handling of requests for aerial spraying and the strengthening of the protection of residents and bystanders. ${ }^{143}$ The Commission concluded that it accepted the compromise

\footnotetext{
${ }^{134}$ European Commission, COM (2008) 457 final [22 July 2008].

135 European Commission, COM (2008) 457 final [22 July 2008] at page 5.

${ }^{136}$ European Commission, COM (2008) 457 final [22 July 2008] at page 5.

137 European Commission, COM (2008) 457 final [22 July 2008] at page 4.

${ }_{138}$ European Parliament, P6-TA (2009) oo10 [13 January 2009]; European Parliament, P6-TC2-COD (2006) 0132 [13 January 2009].

139 European Parliament, P6-TC2-COD (2006) 0132 [13 January 2009].

${ }^{140}$ Committee on the Environment, Public Health and Food Safety, A6-0443/2008 [12 November 2008] at pages 2122.

${ }^{141}$ Committee on the Environment, Public Health and Food Safety, A6-0443/2008 [12 November 2008] at page 21.

${ }^{142}$ European Commission, COM (2009) 63 final [16 February 2009].

143 European Commission, COM (2009) 63 final [16 February 2009] at page 4.
} 
package since it was consistent with the overall purpose and the general characteristics of the proposal. ${ }^{144}$

\section{Council: Decision, 24 September 2009}

On 24 September 2009 the Council officially accepted the amendments of the second reading by the European Parliament. ${ }^{145}$

\section{European Parliament \& the Council: Adoption of Directive , 2 I October 2009}

Approximately one month after the approval of the Council, the Directive was adopted jointly by the European Parliament and the Council. ${ }^{146}$

\section{Final Remarks}

This section has described the internal decision-making process of the EU with respect to the general ban on aerial spraying. It can be concluded that the original proposal of the Commission - which was partly based on the results of the consultation rounds - changed considerably due to amendments of both the European Parliament and the Council. The main points of disagreement were the handling of requests for aerial spraying and the conditions under which derogations would be granted. The European Parliament took a more restrictive approach and prioritised the need to protect human health and the environment. The Council, on the other hand, preferred a higher degree of flexibility in the regulatory framework in order to minimize the administrative burden on the public authorities of Member States. These differences caused considerable delay in the co-decision procedure. Initially, the European Parliament and the Council aimed to adopt the directive in 2008, but it was only at the beginning of 2009 that the two institutions could decide on a compromise package. Then it took another couple of months before the final directive was adopted in October 2009.

\section{Concluding Remarks}

This report has described the EU policy-making process on a highly controversial topic: the general ban on aerial spraying. Starting with the adoption of the Fifth Environment Action Programme in 1993 and the Sixth in 2002, the policy-making process entered the consultation stage in 2002. Multiple consultation rounds were organized by the Commission, including stakeholders' conferences, the submission of stakeholders' written reactions, an expert meeting, and an online interactive policy making consultation. The stakeholders' opinions on a general ban on aerial spraying were strongly divided. Generally, industry, farmers, and helicopter companies opposed a general ban and favoured a more flexible approach. For example, the introduction of legally binding minimum requirements for the use of aerial spraying. Environmental NGOs, consumer groups, and individuals, such as academics and citizens, were generally supportive of a general ban, if not a total ban. Over the course of the consultation

\footnotetext{
144 European Commission, COM (2009) 63 final [16 February 2009] at page 4.

145 Council, Approval of the European Parliament's Amendments at second Reading [24 September 2009].

${ }^{146}$ Directive 2009/128/EC [21 October 2009].
} 
process the voices of those against a general ban were better represented than those in favour of a restrictive ban. However, despite this widespread opposition, the European Commission still decided to use the terminology of a general ban in its proposal for a directive submitted to the European Parliament and the Council in 2006. From 2006 to 2009 the policy-making process followed the steps of the co-decision procedure of the EU. As a result of the various interactions between the European Parliament, the Council, and the Commission, significant changes were incorporated in the Commission's original proposal. The main points of disagreement were the handling of requests for aerial spraying and the conditions under which derogations would be granted. At the beginning of 2008 the European Parliament and the Council managed to reach an agreement on the final text of the Directive. Eventually, after years of delay, the Directive was adopted on 21 October 2009.

Today, the general ban on aerial spraying has been effective for more than six years. Nonetheless the ban remains a controversial topic and is being criticized by both opponents and proponents. For example, in May 2015 the European Commission was requested to respond to a parliamentary question about the implementation of the aerial spraying ban by the Spanish government. The question implied that the Spanish State abused the possibility for derogations by systematically granting emergency permits to the applicators. ${ }^{147}$ The Commission responded in the negative and concluded that Spain had adopted measures that were not in conflict with the provisions for aerial spraying laid down in the Directive of 2009. ${ }^{148}$ At the same time, the Commission acknowledged the need to verify the implementation of the general ban on aerial spraying by Member States. ${ }^{149}$ Thus, it remains to be seen how the aerial spraying ban will further develop in the future and how the different parties will continue their efforts to influence the legislative framework.

\section{Epilogue}

This report has traced the development and outcome of the policy measure in Article 9, the general ban on aerial spraying with possibility for derogation. To contextualise the final policy measure, it is useful to reflect on possible explanations for its formation as well as its implementation. This study did not collected much data on social action and practices beyond what has been mentioned in the various documents, but we hypothesize two possible explanations as to how the originally proposed policy measure with stricter conditions for derogations ended up in the final directive.

First, other research points to the influence of citizen support of lobbying coalitions as well as the relevance of citizens' concerns. In discussing the relevance of different factors for the lobbying and policy outcomes in the EU, Klüver (2013) reflects on the persistence of the ban on aerial spraying as an important element in the proposed Directive. According to her analysis, "the success of the environmental and consumer NGOs can be explained by the relative amount of citizen support they provided to the European Commission" (Klüver, 2013:166). She operationalises citizen support as the amount of (potential) members associated with the respective interest group and included it as a question in her survey. According to her model and quantitative analysis, citizen support was statistically relevant for this particular EU

\footnotetext{
147 Lidia Senra Rodriguez, E-007424-15 [7 May 2015].

${ }^{148}$ European Commission, E-00679/15 E-007424-15 [3 July 2015].

149 European Commission, E-oo679/15 E-007424-15 [3 July 2015].
} 
proposal (Klüver, 2013). Another study, the European Commission's Special Barometer on Risk Issues of 2005, reflects EU citizens' concerns about pesticide exposure. Pesticides and chemicals are among the most frequently worried about risks among EU citizens, and the majority of EU citizens worry about pesticides residues in food (European Commission, Barometer, 2005). It shows that the European Commission was aware of general EU citizens' concerns about pesticide exposure at the time it submitted its proposal to the European Parliament. Both studies thus establish some connection between the policy measure included in the European Commission's proposed Directive and its responsiveness towards citizens, and thus potential future citizen support.

Second, policy-making is being perceived as a bargaining game in which outcomes depend on who sits at the table (telephone interview with PAN representative). As the proposed Directive as a whole was subjected to the policy-making process, banning aerial spraying was seen as a compromise, which granted the industry favourable regulations in other aspects. The composition of the European Parliament at that time was also relevant, since a large group of progressive-minded politicians in the European Parliament supported environmental interest groups in various aspects and pushed for environment-friendly regulations in the Directive. This is reflected, for example, in the early expression of support by the European Parliament towards certain elements of the PURE campaign's suggested Directive and the observations that the European Parliament made the conditions for derogations stricter during the co-decision procedure than in the draft directive submitted by the Commission to the European Parliament and the European Council. After 2009, new politicians in the European Parliament were less progressive and granted more freedoms to DG SANCO again.

Both above explanations seem to fit with observations about a slow and varied implementation. The implementation of the Directive, and in particular the ban on aerial spraying outlined in Article 9, has faced continued opposition against the policy measure. In 2013, PAN Europe reviewed the National Action Plans established by the Member States (PAN Europe 2013). It concluded that in general "Member States' ambition to reduce pesticide use is low" (press release 6.12.16). In particular for aerial spraying, PAN Europe noted that a handful of countries already had a ban in place (Slovenia, Denmark, Estonia, Croatia and Sweden) and others, such as France were considering to change their policy. However, some Member States did not seem to follow the Sustainable Use Directive on Pesticides to PAN's satisfaction. For example, the UK and Hungary did not treat the practise as prohibited in principle, while the Czech Republic's National Action Plan did not include any specifications for aerial spraying, Lithuania had not made any updates to their existing regulations, and Slovakia did not respect the derogation conditions by arguing "for the need to spray in large areas" (p.10). A 2011 European Commission survey on the status of implementation confirmed that implementation in general was sluggish, considering that only 8 out of 20 Member States had finalised their National Action Plans, which were due in 2012. On the topic of aerial spraying the survey painted a more optimistic picture of national policies being close to compliance or Member States having the intention to implement soon. In January 2016, DG SANTE responded to an inquiry on the status of said evaluation of several environmental NGOs, stating the report was being finalised and would be submitted within the Dutch presidency term. In October 2017, the European Commission (2017) sent the evaluation to the European Parliament and Council. With regard to aerial spraying it concluded that all Member States have prohibited aerial spraying under national legislation. However, some Member State still granted derogations, with $95 \%$ of 
the reported aerial spraying taking place in two countries only: Spain (with 339,0oo hectares) and Hungary (with 88,ooo hectares). In other countries the areas treated under derogations had decreased significantly. For example, aerial spraying had been reduced from 17,901 hectares in 2012 to 3389 hectares in Germany in 2015. Even a more dramatic reduction took place in Poland, from 160,506 to 1891 hectares between 2013 and 2016 (European Commission 2017). Although it took a while, the pressure of social movements to reduce aerial spraying via legislation seems to have contributed to significant changes in spraying practices. 


\section{References}

\section{EU Law}

EU Law, Directive 2009/128/EC of the European Parliament and of the Council establishing a framework for Community action to achieve a sustainable use of pesticides [21 October 2009].

EU Law, Treaty of Lisbon, Amending the Treaty of the European Union and the Treaty Establishing the European Community [signed on 13 December 2007, entry into force on 1 December 2009].

EU Law, Treaty on the Functioning of the European Union [signed on 13 December 2007, entry into force on 1 December 2009].

\section{Communications from European Commission}

European Commission, COM (2001) ooz1 final, Communication from the Commission to the Council, the European Parliament, the Economic and Social Committee and the Committee of Regions on the Sixth Environment Action Programme of the European Community "Environment 2010: Our Future, Our Choice" [24 January 2001].

European Commission, COM (2002) 349 final, Communication from the Commission to the Council, the European Parliament and the Economic and Social Committee, Towards a Thematic Strategy on the Sustainable Use of Pesticides [1 July 2002].

European Commission, COM (2006) 373 final, Proposal for a Directive of the European Parliament and of the Council establishing a framework for Community action to achieve a sustainable use of pesticides [12 July 2006]

European Commission, COM (2017) 587 final, Report from the Commission to the European Parliament and the Council: On Member State National Action Plans and on Progress in the Implementation of Directive 2009/128/EC on the Sustainable Use of Pesticides. [10.10.2017].

\section{Consultation Documents 2002-2005 (Stakeholders \& EU Institutions)}

Association de Défense, d'Education et d'Information du Consommateur, Opinion on Assessing economic impacts of specific measures to be part of the Thematic Strategy on the Sustainable Use of Pesticides [31 January 2005].

Association of Users and Distributors of Agrochemicals in Europe, The Contribution of AUDACE to a Thematic Strategy on the Sustainable Use of Pesticides [8 November 2002].

Association of Users and Distributors of Agrochemicals in Europe, In Response to the BIPRO Report [31 January 2005].

Crop Protection Association UK Ltd, Comments on the Commission Communication: Towards a Thematic Strategy on the Sustainable Use of Pesticides (COM 2002/343 final) [2002].

Crop Protection Association UK Ltd, Opinion on Assessing economic impacts of specific measures to be part of the Thematic Strategy on the Sustainable Use of Pesticides (Final Report, October 2004) [10 February 2005].

Directorate-General Environment of the European Commission, Thematic Strategy on the Sustainable Use of Pesticides, Expert Meeting on Aerial Spraying, Minutes of the meeting [31 March 2004].

European Association of Craft, Small and Medium-Sized Enterprises, UEPMA's Comments to the Document: "Assessing economic impacts of the specific measures to be part of the Thematic Strategy on the Sustainable Use of Pesticides" [29 January 2005].

European Council, 15101/o2, Council Conclusions on the Sustainable Use of Pesticides [9 December 2002]. European Crop Protection Association, ECPA Comments on the BIPRO Report [30 January 2005]. European Economic and Social Committee, NAT/156, Opinion on the Communication from the

Commission to the Council, the European Parliament and the European Economic and Social Committee: Towards a thematic strategy on the sustainable use of pesticides [23 January 2003]. 
European Parliament, $\mathrm{P}_{5}$ TA(2003) 0128, Resolution: Towards a thematic strategy on the sustainable use of pesticides (2002/2277 (INI)) [27 March 2003].

Germany Helicopter Association, Opinion of Volker Grasberger on behalf of the Aerial Work Committee [31 January 2005].

Groupement Français de l'Hélicoptère, Comments on the Commission Communication [1o March 2003]

Howard, C. V., Response to the Consultation on the Document: "Towards a Thematic Strategy on the Use of Pesticides" [31 October 2002].

National Farmers Union UK, Consultant Report on EU Thematic Strategy on Pesticides [31 January 2005].

Pesticides Action Network Europe \& European Environmental Bureau, Comments on the European Commission's Communication “Towards a Thematic Strategy on the Use of Pesticides" [2002].

Pesticides Action Network Europe, Comments on the October 2004 Extended Impact Assessment entitled: "Assessing economic impacts of the specific measures to be part of the Thematic Strategy on the Use of Pesticides" [February 2005].

Proceedings of the Stakeholders' Conference on the Development of a Thematic Strategy on the Sustainable Use of Pesticides, Brussels [4 November 2002].

\section{Impact Assessments (BiPRO \& European Commission)}

BiPRO, Assessing Economic Impacts of the Specific Measures to be part of the Thematic Strategy on the Sustainable Use of Pesticides: Exploring Policy Option for Selected Measures [17 February 2004].

BiPRO, Assessing Economic Impacts of the Specific Measures to be part of the Thematic Strategy on the Sustainable Use of Pesticides: Final Report, ENV.C.4/ETU/2003/o094R [October 2004].

European Commission, SEC (2006) 894, Commission Staff Working Paper: The Impact Assessment of the Thematic Strategy on the Sustainable Use of Pesticides - Accompanying the Proposal for a Directive of the European Parliament and of the Council establishing a framework for Community action to achieve a sustainable use of pesticides [12 July 2007].

\section{Co-Decision Procedure 2006-2009}

Committee of Regions, 2007/C 146/o6, Opinion of the Committee of Regions on the Thematic Strategy on the Sustainable Use of Pesticides [13 February 2007].

Committee on the Environment, Public Health and Food Safety, A6-0443/2008, Recommendation for Second Reading on the Council common position for adopting a directive of the European Parliament and of the Council establishing a framework for Community action to achieve a sustainable use of pesticides [12 November 2008].

Council, Common Position (EC) No. 21/2008 Adopted by the Council on 19 May 2008 with a view to the adoption of Directive 2008/.../EC of the European Parliament and of the Council of ... establishing a framework for Community action to achieve the sustainable use of pesticides [19 May 2008].

Council, Approval of the European Parliament's Amendments at $2^{\text {nd }}$ Reading [24 September 2009].

European Commission, Common Position on European Parliament's Amendments on 1st Reading: European Parliament legislative resolution on the Proposal for a Directive of the European Parliament and of the Council establishing a framework for Community action to achieve the sustainable use of pesticides [23 October 2007].

European Commission, COM (2008) 457 final, Communication from the Commission to the European Parliament pursuant to the second subparagraph of Article 251(2) of the EC Treaty concerning the common position of the Council on the adoption of a Directive of the European Parliament and of the Council establishing a framework for Community action to achieve the sustainable use of pesticides [22 July 2008].

European Commission, COM (2009) 63 final, Opinion of the Commission pursuant Article 251(2), third subparagraph, point (c) of the EC Treaty, on the European Parliament's amendments to the Council's Common Position regarding a Proposal for a Directive of the European Parliament and 
of the Council establishing a framework for Community action to achieve a sustainable use of pesticides [16 February 2009].

European Economic and Social Committee, 2007/C 161/15, Opinion of the European Economic and Social Committee on the Proposal of a Draft Directive of the European Parliament and of the Council establishing a framework for Community action to achieve a sustainable use of pesticides [14 March 2007].

European Parliament, Final A6-0347/2007, Report on the Proposal for a Directive of the European Parliament and of the Council establishing a framework for Community action to achieve a sustainable use of pesticides (COM(2006)0373 - C6-0246/2006 - 2006/0132(COD)) [26 September 2007].

European Parliament, P6_TC1-COD(2006)o132, Position of the European Parliament adopted at first reading on 23 October 2007 with a view to the adoption of Directive 2008/.../EC of the European Parliament and of the Council establishing a framework for Community action to achieve a sustainable use of pesticides [23 October 2007].

European Parliament, P6_TA(2007) 0444, European Parliament legislative resolution of 23 October 2007 on the proposal for a directive of the European Parliament and of the Council establishing a framework for Community action to achieve a sustainable use of pesticides (COM(2006)0373 - C60246/2006 - 2006/0132(COD)) [23 October 2007].

European Parliament, P6-TA (2009) oo10, European Parliament's legislative resolution of 13 January 2009 on the Council common position for adopting a directive of the European Parliament and of the Council establishing a framework for Community action to achieve a sustainable use of pesticides (6124/2008-C6-0323/2008-2006/0132 (COD)) [13 January 2009].

European Parliament, P6-TC2-COD (2006) 0132, Position of the European Parliament adopted at the second reading on 13 January 2009 with a view to the adoption of Directive 2009/.../EC of the European Parliament and of the Council establishing a framework for Community action to achieve the sustainable use of pesticides [13 January 2009].

\section{Miscellaneous}

Barraza, D., Jansen, K., van Wendel de Joode, B. and Wesseling, C. (2013) Social Movements and Risk Perception: Unions, Churches, Pesticides and Bananas in Costa Rica, International Journal of Occupational and Environmental Health, 19(1): 11-21.

European Commission, E-0o679/15 E-o07424-15, Joint answer given by Mr. Andriukaitis on behalf of the Commission [3 July 2015].

European Communities, "EU Policy for a Sustainable Use of Pesticides - The story behind the Strategy" [2007].

Fifth Environment Action Programme "Towards Sustainability": A European Community programme of policy and action in relation to the environment and sustainable development [1 February 1993].

Fifth Environment Action Programme (revised) “Towards Sustainability”, Decision No. 2179/98/EC of the European Parliament and of the Council on the Review of the European Community programme of policy and action in relation to the environment and sustainable development [28 September 1998].

Jansen, K. (2004) Greening Bananas and Institutionalizing Environmentalism: Self-regulation by Fruit Corporations, in Jansen, K. and Vellema, S. (eds) Agribusiness and Society: Corporate Responses to Environmentalism, Market Opportunities and Public Regulation, pp. 145-175. London: Zed.

Jansen, K. (2009) Implicit Sociology, Interdisciplinarity and Systems Theories in Agricultural Science, Sociologia Ruralis, 49(2): 172-188.

Jansen, K. (2017) Business Conflict and Risk Regulation: Understanding the Influence of the Pesticide Industry, Global Environmental Politics, 17(4): 48-66. 
Jansen, K. and Dubois, M. (2014) Global Pesticide Governance by Disclosure: Prior Informed Consent and the Rotterdam Convention, in Gupta, A. and Mason, M. (eds) Transparency in Global Environmental Governance: Critical Perspectives, pp. 107-131. Cambridge: MIT Press.

Klüver, H. (2013) Lobbying in the European Union: Interest Groups, Lobbying Coalitions, and Policy Change, Oxford: Oxford University Press.

Lidia Senra Rodriguez, E-o07424-15, Question for written answer to the Commission pursuant Rule 130 [7 May 2015].

Nikol, L. and Jansen, K. (2019) The Politics of Counter-Expertise on Aerial Spraying: Social Movements Denouncing Pesticide Risks in the Philippines, Journal of Contemporary Asia, https://doi.org/10.1080/00472336.2018.1551962.

Oppenheimer, Wolff \& Donnelly, "Possibilities for Future E.U. Environmental Policy on Plant Production Products: Synthesis Report", Commissioned by the European Commission. Report presented during the Second Workshop on a framework for the Sustainable Use of Plant Protection Products in the European Union, Brussels [May 1998].

PAN Europe (2002) Suggested text for a Directive of the European Parliament and of the Council on measures for reduction of use and of impacts to health and environment from pesticides. PAN UK: London.

PAN Europe (2013) Reducing Pesticide Use Across the EU. Brussels: Pesticide Action Network Europe.

PAN Europe (2016) The EC is over 2 years late in Delivering the Mandated Report on Implementation of SUDP. www.pan-europe.info/press-releases/2016/12/ec-over-2-years-late-delivering-mandatedreport-implementation-sudp (Retrieved 3 December 2018).

Press Release, C/06/251, 275oth Council Meeting, Agriculture and Fisheries, Brussels [18 September 2008], http://europa.eu/rapid/press-release_PRES-o6-251_en.htm?locale=en (retrieved 4 May 2016).

Press Release C/o7/294, 2841 ${ }^{\text {st }}$ Council Meeting, Agriculture and Fisheries, Brussels [17-19 December 2007], (retrieved 4 May 2016).

Proceedings of the Second Workshop on a framework for the Sustainable Use of Plant Protection Products in the European Union, Brussels [12-14 May 1998].

Sixth Environment Action Programme, Decision No. 1600/2002/EC of the European Parliament and of the Council laying down the Sixth Community Environment Action Programme [22 July 2002].

Toleubayev, K., Jansen, K. and Van Huis, A. (2011) From Integrated Pest Management to Indiscriminate Pesticide Use in Kazakhstan, Journal of Sustainable Agriculture, 35(4):350-375. 


\section{Annex I \\ Directive 2009/128/EC of the European Parliament and of the Council establishing a framework for Community action to achieve the sustainable use of pesticides \\ 21 October 2009 \\ Article 9 \\ Aerial spraying}

1. Member States shall ensure that aerial spraying is prohibited.

2. By way of derogation from paragraph 1 aerial spraying may only be allowed in special cases provided the following conditions are met:

(a) there must be no viable alternatives, or there must be clear advantages in terms of reduced impacts on human health and the environment as compared with land-based application of pesticides;

(b) the pesticides used must be explicitly approved for aerial spraying by the Member State following a specific assessment addressing risks from aerial spraying;

(c) the operator carrying out the aerial spraying must hold a certificate as referred to in Article 5(2). During the transitional period where certification systems are not yet in place, Member States may accept other evidence of sufficient knowledge;

(d) the enterprise responsible for providing aerial spray applications shall be certified by a competent authority for authorising equipment and aircraft for aerial application of pesticides;

(e) if the area to be sprayed is in close proximity to areas open to the public, specific risk management measures to ensure that there are no adverse effects on the health of bystanders shall be included in the approval. The area to be sprayed shall not be in close proximity to residential areas;

(f) as from 2013, the aircraft shall be equipped with accessories that constitute the best available technology to reduce spray drift.

3. Member States shall designate the authorities competent for establishing the specific conditions by which aerial spraying may be carried out, for examining requests pursuant to paragraph 4 and for making public information on crops, areas, circumstances and particular requirements for application including weather conditions where aerial spraying may be allowed. 
In the approval the competent authorities shall specify the measures necessary for warning residents and bystanders in due time and to protect the environment in the vicinity of the area sprayed.

4. A professional user wishing to apply pesticides by aerial spraying shall submit a request for approval of an application plan to the competent authority accompanied by evidence to show that the conditions referred to in paragraphs 2 and 3 are fulfilled. The request for application of aerial spraying in accordance with the approved application plan shall be submitted in due time to the competent authority. It shall contain information about the provisional time of spraying and the amounts and the type of pesticides applied.

Member States may provide that requests for applications of aerial spraying in accordance with an approved application plan, for which no answer was received on the decision taken within the time period laid down by the competent authorities, shall be deemed to be approved.

In particular circumstances such as emergency or specific difficult situations, single requests for application of aerial spraying may also be submitted for approval. Where justified, competent authorities shall have a possibility to apply an accelerated procedure in order to verify that the conditions referred to in paragraphs 2 and 3 are fulfilled before the application of aerial spraying.

5. Member States shall ensure that the conditions referred to in paragraphs 2 and 3 are met by conducting appropriate monitoring.

6. The competent authorities shall keep records of the requests and approvals as referred to in paragraph 4 and shall make available to the public the relevant information contained therein such as the area to be sprayed, the provisional day and time of the spraying and the type of pesticide, in accordance with the applicable national or Community law. 


\section{Annex II}

\section{COM (2006) 373 final}

Proposal for a Draft Directive of the European Parliament and of the Council establishing a framework for Community action to achieve a sustainable use of pesticides

12 July 2006

\section{Article 9 Aerial spraying}

1. Member States shall prohibit aerial spraying subject to paragraphs 2-6.

2. Member States shall define and make public crops, areas and particular requirements for application, where by way of derogation from paragraph 1 , aerial spraying may be authorised.

3. Member States shall designate the authorities competent for granting derogations, and inform the Commission thereof.

4. Derogations may only be granted where the following conditions are fulfilled:

(a) there must be no viable alternatives, or there must be clear advantages in terms of reduced impacts on health and the environment in comparison to land-based application of pesticides

(b) the pesticides used must be explicitly authorised for aerial spraying

(c) the operator carrying out the aerial spraying must hold a certificate referred to in Article 5(2).

The authorisation shall specify the measures necessary for warning residents, bystanders and for protecting the environment in the vicinity of the area sprayed.

5. A professional user wishing to apply pesticides by aerial spraying shall submit a request to the competent authority accompanied by data supporting that the conditions referred to in paragraph 4 are fulfilled.

6. The competent authorities shall keep records of derogations granted. 


\section{Annex III}

\section{P6_TC1-COD(2006)o132}

Position of the European Parliament adopted at first reading on 23 October 2007 with a view to the adoption of Directive 20o8/.../EC of the European Parliament and of the Council establishing a framework for Community action to achieve a sustainable use of pesticides

23 October 2007

Article 9 Aerial spraying

1. Member States shall prohibit aerial spraying subject to paragraphs 2-6.

2. Member States shall define and make public crops, areas and particular requirements for application, where by way of derogation from paragraph 1, aerial spraying may be authorised.

3. Member States shall designate the authorities competent for monitoring aerial spraying, and inform the Commission thereof.

4. Derogations may only be granted where the following conditions are fulfilled:

(a) there must be no viable alternatives, or there must be clear advantages in terms of reduced impacts on human health and the environment in comparison to land-based application of pesticides;

(b) the pesticides used must be explicitly authorised for aerial spraying; substances classified as very toxic $\left(\mathrm{R}_{50}\right)$ to aquatic organisms shall not be authorised for aerial spraying;

(c) the pilot or operator preparing and carrying out the aerial spraying must hold a certificate referred to in Article 5(3);

(d) aerial spraying must be notified in advance to the competent authority and authorised by that authority;

(e) all the requisite measures must be taken in order to provide warning in good time for residents and bystanders and to protect the environment in the vicinity of the area sprayed;

(f) the area to be sprayed must not be in close proximity to public or residential areas and there must be no effects on the health of residents or bystanders;

(g) the aerial craft must be equipped with the best available technology to reduce spray drift (e.g. lowdrift nozzles); where helicopters are used, the spray booms must be equipped with injection jets to reduce drift;

(h) the socio-economic and environmental benefits must outweigh the potential effects

on the health of residents and bystanders.

5. A professional user wishing to apply pesticides by aerial spraying shall submit a request to the competent authority accompanied by data supporting that the conditions referred to in paragraph 4 are fulfilled. The notification shall contain information about the time of spraying and the amounts and the type of pesticides applied.

6. The competent authorities shall keep records of derogations granted and shall make them available to the public.

$\underline{\text { Underlined }}=$ European Parliament's changes of and additions to the Commission's Proposal 


\section{Annex}

IV

Common Position (EC) No. 21/2008 Adopted by the Council on 19 May 2008 with a view to the adoption of Directive 2008/.../EC of the European Parliament and of the Council of ... establishing a framework for Community action to achieve the sustainable use of pesticides

19 May 2008

Article 9 Aerial spraying

1. Member States shall ensure that aerial spraying is prohibited.

2. By way of derogation from paragraph 1 aerial spraying may only be allowed in special cases provided the following conditions are met:

(a) there must be no viable alternatives, or there must be clear advantages in terms of reduced impacts on human health and the environment as compared with land-based application of pesticides;

(b) the pesticides used must be explicitly approved for aerial spraying by the Member State following a specific assessment addressing risks from aerial spraying; substances classified as very toxic ( $\mathrm{R}_{50}$ ) to aquatic organisms shall not be authorised for aerial spraying.

(c) the pilot or operator preparing or-carrying out the aerial spraying must hold a certificate as referred to in Article 5(2). During the transitional period where certification systems are not yet in place, Member States may accept other proof of competence;

(d) the enterprise responsible for providing aerial spray applications shall be certified by a competent authority for authorising equipment and aircraft for aerial application of pesticides.

(d) aerial spraying must be notified in advance to the competent authority and authorised by that authority;

(e) all the requisite measures must be taken in order to provide warning in good time for residents and bystanders and to protect the environment in the vicinity of the area sprayed;

(f) the area to be sprayed must not be in close proximity to public or residential areas and there must be no effects on the health of residents or bystanders;

(g) the aerial craft must be equipped with the best available technology to reduce spray drift (e.g. low drift nozzles); where helicopters are used, the spray booms must be equipped with injection jets to reduce drift;

(h) the socio-economic and environmental benefits must outweigh the potential effects on the health of residents and bystanders.

3. Member States shall designate the authorities competent for establishing the specific conditions by which aerial spraying may be carried out and make public information on crops, areas, circumstances and particular requirements for application including weather conditions where aerial spraying may be allowed. 
The competent authorities shall specify the measures necessary for warning residents and bystanders and to protect the environment in the vicinity of the area sprayed.

4. A professional user wishing to apply pesticides by aerial spraying shall submit a request in due time to the competent authority to apply pesticides by aerial spraying accompanied by evidence to show that the conditions referred to in paragraphs 2 and 3 are fulfilled. The notification shall contain information about the time of spraying, the amounts and the type of pesticides applied.

Member States may provide that requests for which no answer was received on the decision taken within the time period laid down by the competent authorities shall be deemed to be approved.

5. Member States shall ensure that the conditions referred to in paragraphs 2 and 3 are met by conducting appropriate monitoring;

6. The competent authorities shall keep records of the requests submitted under paragraph 4 and make the records on the derogations granted available to the public.

Underlined $=$ Council's changes of and additions to Commission's proposal.

Strikethrough $=$ Council's disapproval of European Parliament's amendments.

Italics $=$ Council's approval of European Parliament's amendments.

Underlined = European Parliament's amendments partly approved by the Council. 